\title{
Risk of Cardiovascular Events in Patients with Primary Biliary Cholangitis - Systematic Review
}

\author{
Duminda Suraweera ${ }^{1}$, Christina Fanous ${ }^{2}$, Melissa Jimenez $^{2}$, Myron J. Tong ${ }^{3}$ \\ and Sammy Saab*2,4 \\ ${ }^{1}$ Department of Medicine, Olive-View Medical Center, Sylmar, CA, USA; ${ }^{2}$ Department of Surgery at the University of California at \\ Los Angeles, Los Angeles, CA, USA; ${ }^{3}$ Huntington Research Institute, Pasadena, CA, USA; ${ }^{4}$ Department of Medicine at the
} University of California at Los Angeles, Los Angeles, CA, USA

\begin{abstract}
Background and Aims: Hypercholesterolemia is a common finding in patients with primary biliary cholangitis (PBC) and is a well-defined risk factor for cardiovascular disease. However, studies have been mixed on whether PBC patients do, in fact, have higher cardiovascular risk. The aim of this study is to review the current literature and provide an evidence-based assessment of cardiovascular risk in PBC patients. Methods: We performed a systematic literature search on PubMed regarding patients with $\mathrm{PBC}$ and cardiovascular events from the database inception to July 1,2017 . A total of 33 articles fulfilling our inclusion criteria were found. Results: The majority of the studies evaluated yielded no statistically significant difference in cardiovascular disease in the PBC population compared to the general public. However, some reports found a statistically significantly increase in coronary artery disease. Several studies have looked at the specific lipid profile of patients with PBC with hypocholesteremia. While these lipid abnormalities differ by stage of disease, there is evidence to suggest that the specific lipid profile in PBC may have lower atherogenicity than in patients with hypercholesterolemia without PBC. Studies looking at patients with PBC with other risk factors for cardiovascular disease, such as hypertension and metabolic syndrome, have consistently found a higher risk for cardiovascular disease in these patients. Statin treatment is effective in reducing lipid levels and possibly improving endothelial inflammation in patients with PBC with hypercholesterolemia. Conclusions: There is not enough evidence to suggest an increased risk of cardiovascular disease in patients with PBC with hypercholesterolemia, except for those individuals with concomitant features of metabolic syndrome. In patients with PBC with no additional cardiovascular risk factors, individual risk/benefit discussion on lipidlowering treatment should be considered.
\end{abstract}

Citation of this article: Suraweera D, Fanous C, Jimenez M, Tong MJ, Saab S. Risk of cardiovascular events in patients with

Keywords: Primary biliary cholangitis (PBC); Cardiovascular risk; Hypercholesterolemia Abbreviations: $\mathrm{CI}$, confidence interval; $\mathrm{HDL}$, high density lipoprotein; $H R$, hazard ratio; IMT, intima-media thickness; LDL, low density lipoprotein; NASH non-alcoholic steatohepatitis; PBC, primary biliary cholangitis; UDCA, ursodeoxycholic acid; VLDL, very low density lipoproteins.

Received: 7 October 2017; Revised: 14 December 2017; Accepted: 2 January 2018

*Correspondence to: Sammy Saab, Pfleger Liver Institute, UCLA Medical Center, 200 Medical Plaza, Suite 214, Los Angeles, CA 90095, USA. Tel: +1-310-2066705, Fax: +1-310-206-4197, E-mail: SSaab@mednet.ucla.edu primary biliary cholangitis - systematic review. J Clin Transl Hepatol 2018;6(2):119-126. doi: 10.14218/JCTH.2017.00064.

\section{Introduction}

Hypercholesterolemia is a well-defined risk factor for cardiovascular disease in the general population. ${ }^{1}$ However, in patients with primary biliary cholangitis (PBC; formerly known as primary biliary cirrhosis), the role of hypercholesterolemia in cardiovascular disease remains unclear. PBC is an autoimmune, cholestatic liver disease that results in progressive destruction of the intrahepatic bile ducts, leading to chronic liver damage. ${ }^{2}$ The incidence of PBC ranges from 0.33 to 5.8 per 100,000 /year, with a prevalence rate of 1.91 to 49.2 per $100,000 .^{3}$ The peak incidence of PBC corresponds to middle-age, with women being affected at a higher rate (of 9 to 1 ). ${ }^{3}$ The clinical presentation of PBC can be divided into four stages. The preclinical stage is marked by the presence of a positive antimitochondrial antibody, without any symptoms or other lab abnormalities. The asymptomatic stage includes the development of abnormal liver tests, while remaining asymptomatic. The third stage involves the development of symptoms such as fatigue and pruritus. Lastly, the development of cirrhosis and liver failure marks the fourth and final stage of PBC. ${ }^{4,5}$

Lipid abnormalities are a common laboratory finding in patients with PBC. However, studies have been mixed on whether these abnormalities translate to an increase in cardiac and cerebrovascular risk. Several studies have concluded that patients with PBC may have impaired cardiovascular function. ${ }^{6-9}$ Other studies found no increase in cardiovascular events in PBC patients. ${ }^{9-14}$ In this review, we aim to evaluate the current literature available on PBC and cardiovascular risk, with the goal of providing an evidencebased assessment of cardiovascular risk in PBC patients. Furthermore, we aim to provide guidance for future areas of investigation in this area.

\section{Methods}

\section{Search strategy}

We searched the PubMed database for all studies regarding patients with PBC and cardiovascular events from its inception to July 1, 2017. We used a combination of the keywords 'primary biliary cirrhosis', 'primary biliary cholangitis', 'atherosclerosis', 'coronary artery disease', 'hypercholesterolemia' 
and 'cardiovascular events'. We also manually searched manuscript references to identify additional studies that may have been missed with a MEDLINE-assisted strategy. Two reviewers independently and in duplicate assessed the eligibly of the studies (Fig. 1).

\section{Inclusion and exclusion criteria}

We included all English language studies published in scientific journals that provided data about cholesterol levels (including total cholesterol, low density lipoprotein (LDL), high density lipoprotein (HDL), and triglycerides), cardiovascular risk and lipid-lowering treatment of adult patients with PBC.

\section{Results}

\section{Cardiovascular risk}

In light of the high prevalence of hypercholesterolemia in patients with PBC, several studies have evaluated the cardiovascular risk in this population (Table 1 ). Most studies have not found an increased cardiovascular risk in PBC patients. Doycheva et al. ${ }^{10}$ evaluated 180 patients with PBC compared to 151 controls and found that there was no statistically significant difference in rates of developing cardiovascular disease ( $10 \%$ in PBC and $7 \%$ in controls, $p=0.3$ ). Of note, although the two groups had no baseline differences in prevalence of hypertension or diabetes, there was a statistically higher rate of tobacco use in the control group than in the PBC group (63.6\% vs. $35 \%, p<0.001)$. In a large population-based cohort study involving 930 patients with PBC and 9,000 controls, no statistical difference was found in the rates of any vascular event (hazard ratio (HR): $0.99,95 \%$ confidence interval (CI): 0.77-1.27), myocardial infarction (HR: $1.04,95 \% \mathrm{CI}$ : 0.67-1.62), stroke (HR: $0.98,95 \% \mathrm{CI}: 0.73-1.31$ ) or transient ischemic attack (HR: $0.66,95 \% \mathrm{CI}: 0.38-1.16) .{ }^{15}$ Another retrospective analysis of Dutch PBC deaths from 1979 to 1992 found no statistical difference in standardized mortality ratios of ischemic heart disease and acute myocardial infarction

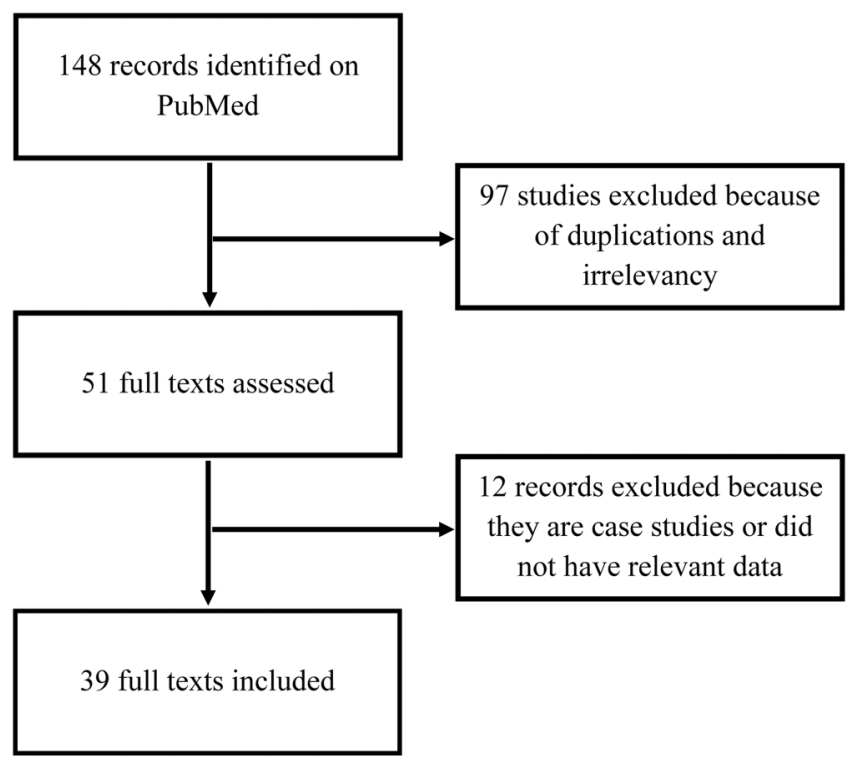

Fig. 1. Search methodology outline. from the control group. ${ }^{16} \mathrm{~A}$ prospective, USA-based study on 312 patients with PBC, who were followed for a median of 7.4 years, found that the incidence of atherosclerotic death was not statistically different when compared with an age-matched and sex-matched USA control population. ${ }^{17}$

Conversely, some studies have shown a possible increased risk of cardiovascular disease in patients with PBC. A large Swedish study of hospitalized patients with a main diagnosis of immune-mediated disease $(336,479$ patients) without coexisting coronary heart disease were followed from the time of first hospitalization for coronary heart disease. ${ }^{14}$ Using the total population of Sweden as a reference, standardized incidence ratios for coronary heart disease were calculated, with PBC having a ratio of 3.32 (95\% CI: $2.34-4.58$ ). In addition, a systematic review and meta-analysis of four observational studies found a statistically significant increase in the risk of coronary artery disease. ${ }^{9}$ A total of 3,362 patients and 413,619 controls met the inclusion criteria for those authors, and a relative risk of 1.57 (95\% CI, 1.21-2.06) was found. It was concluded that there could be an increased risk of coronary artery disease in patients with PBC and that the majority of previous studies may have not found a significant difference due to limitations in sample size. Another systematic review and meta-analysis done by the same authors on the risk of cerebrovascular disease in patients with PBC did not find a statistically significant increase in risk. ${ }^{13}$ While the studies showing an increased cardiovascular risk in patients with PBC are certainly a minority, it is important to note that it may be that current studies did not have the sample size and longitudinal follow-up needed to discern a risk, a conclusion also reached by another systematic review. ${ }^{18}$

\section{Atherogenesis}

Atherogenesis is a disruption in the arterial wall due to a complex series of events involving lipid deposition, that is the basis atherosclerotic cardiovascular disease. Some studies have shown that hypercholesterolemia in PBC may not have the same level of atherogenesis as seen in the general population. This may be due to the specific lipid profile exhibited by PBC patients (Table 2). ${ }^{19}$ One small study found that patients with PBC tended to have increased levels of plasma HDLs and decreased platelet aggregation, which may contribute to the relatively low degree of atherogenicity seen in this population. ${ }^{20}$ Other studies have also found that patients with PBC with hypercholesterolemia also tend to have elevated HDL levels. ${ }^{17}$

HDL is known to have a protective effect against cardiovascular disease. ${ }^{21}$ Apolipoprotein A1 and A2 are the major proteins in HDL. There are two major classes of apolipoprotein A1-containing lipoproteins: LPA1, which contains apolipoprotein $\mathrm{A} 1$ but not $\mathrm{A} 2$; and, LPA1:A2, which contains both. ${ }^{22}$ There is evidence that LpA1 may have antiatherogenic properties. ${ }^{23}$ A study measuring levels of these apolipoproteins in 31 patients with PBC found that LPA1 concentrations were greatly increased in those patients. ${ }^{24}$ Furthermore, the fraction of total apolipoprotein $\mathrm{A} 1$ was greater in the patients with PBC. The authors concluded that PBC is likely associated with an altered distribution of apolipoprotein A1, favoring an increased concentration of the protective LpA-I particles.

Lipoprotein(a) is an independent risk factor for atherosclerosis, and high serum concentrations of lipoprotein(a) have been found in patients with coronary heart disease. ${ }^{25}$ Patients with hypercholesterolemia associated with PBC may 
Suraweera D. et al: Cardiovascular risk in PBC

Table 1. Primary studies evaluating cardiovascular risk in patients with primary biliary cholangitis

\begin{tabular}{|c|c|c|c|c|c|}
\hline Author & Country & Methodology & Period & Comparison groups & Findings \\
\hline $\begin{array}{l}\text { Crippin et al. }{ }^{17} \\
1992\end{array}$ & USA & $\begin{array}{l}\text { Prospective } \\
\text { cohort study }\end{array}$ & $\begin{array}{l}\text { Median } \\
7.4 \text { years }\end{array}$ & $\begin{array}{l}312 \text { patients with PBC } \\
\text { compared to age- and } \\
\text { sex-matched controls }\end{array}$ & $\begin{array}{l}\text { No statistically } \\
\text { significant difference }\end{array}$ \\
\hline $\begin{array}{l}\text { Van Dam et al. }{ }^{16} \\
1997\end{array}$ & Netherlands & $\begin{array}{l}\text { Retrospective } \\
\text { cohort study }\end{array}$ & $\begin{array}{l}13 \text { years } \\
(1979-1992)\end{array}$ & $\begin{array}{l}597 \text { PBC-related } \\
\text { deaths compared to } \\
\text { age- and sex-matched } \\
\text { controls }\end{array}$ & $\begin{array}{l}\text { No statistically } \\
\text { significant difference }\end{array}$ \\
\hline $\begin{array}{l}\text { Longo et al. }{ }^{37} \\
2002\end{array}$ & Italy & $\begin{array}{l}\text { Prospective } \\
\text { cohort study }\end{array}$ & $\begin{array}{l}\text { Median } \\
6.2 \text { years }\end{array}$ & $\begin{array}{l}400 \text { patients with PBC } \\
\text { compared to rates of } \\
\text { disease in general } \\
\text { population }\end{array}$ & $\begin{array}{l}\text { No statistically } \\
\text { significant difference }\end{array}$ \\
\hline $\begin{array}{l}\text { Solaymani et al. }{ }^{15} \\
2008\end{array}$ & UK & $\begin{array}{l}\text { Retrospective } \\
\text { cohort study }\end{array}$ & $\begin{array}{l}43,700 \\
\text { person-years } \\
\text { of follow-up }\end{array}$ & $\begin{array}{l}930 \text { patients with PBC } \\
\text { compared to } 9,202 \\
\text { age- and sex-matched } \\
\text { controls }\end{array}$ & $\begin{array}{l}\text { No statistically } \\
\text { significant difference }\end{array}$ \\
\hline $\begin{array}{l}\text { Doycheva et al. }{ }^{10} \\
2011\end{array}$ & USA & $\begin{array}{l}\text { Prospective } \\
\text { cohort study }\end{array}$ & $2.9 \pm 2.8$ years & $\begin{array}{l}180 \text { patients with PBC } \\
\text { and } 151 \text { controls with } \\
\text { chronic HCV (No } \\
\text { differences in } \\
\text { hypertension, } \\
\text { diabetes, obesity. PBC } \\
\text { group with high total } \\
\text { cholesterol. Control } \\
\text { group with higher } \\
\text { tobacco use) }\end{array}$ & $\begin{array}{l}\text { No statistically } \\
\text { significant difference }\end{array}$ \\
\hline Zoller et al. ${ }^{14} 2012$ & Sweden & $\begin{array}{l}\text { Retrospective } \\
\text { cohort study }\end{array}$ & $\begin{array}{l}44 \text { years } \\
(1964-2008)\end{array}$ & $\begin{array}{l}336,479 \text { patients with } \\
\text { immune-mediated } \\
\text { disease compared to } \\
\text { general Swedish } \\
\text { population }\end{array}$ & $\begin{array}{l}\text { Statistically significant } \\
\text { increase in coronary } \\
\text { heart disease in PBC } \\
\text { patients. Standardized } \\
\text { incidence ratio of } 3.32 \\
\text { ( } 95 \% \text { CI: } 2.34-4.58) \text {. }\end{array}$ \\
\hline
\end{tabular}

have levels of lipoprotein(a) similar to controls without hypercholesterolemia. A study evaluating serum lipid levels in 39 patients with PBC compared to 29 controls found that, despite an elevation of overall lipoproteins in the PBC patients, there was no difference in lipoprotein(a) levels between the two groups $(10 \mathrm{mg} / \mathrm{dL}$ vs. $11.5 \mathrm{mg} / \mathrm{dL}, p=0.64) .{ }^{26} \mathrm{~A}$ similar conclusion was reached in a study by Gregory et al. ${ }^{27}$ comparing 42 patients with PBC, 39 matched non-PBC liver disease patients and 432 community control subjects. The authors found that there was a reduction of lipoprotein(a) concentrations in the PBC group compared with the healthy controls ( $28.5 \mathrm{mg} / \mathrm{L}$ vs. $75.0 \mathrm{mg} / \mathrm{L}, p<0.005$ ) and non-significant reduction when compared to the non-PBC liver disease group $(52.0 \mathrm{mg} / \mathrm{L})$. Within both the liver disease and PBC patient groups there were significant negative correlations between lipoprotein(a) levels and bilirubin $(R=-0.564, p<0.001$ and $\mathrm{R}=-0.395, p=0.010$ respectively). Of note, one study evaluating serum homocysteine and lipoprotein levels in chronic liver disease patients, including patients with PBC, postmethionine load suggested that levels of lipoprotein(a) were similar to controls without chronic liver disease. ${ }^{28}$

Another important component of the atherogenic process is adiponectin, an antiatherogenic factor that has been shown to have a protective affect against atherosclerosis and metabolic syndrome. ${ }^{29,30}$ A study comparing 137 patients with $\mathrm{PBC}, 30$ patients with non-alcoholic steatohepatitis (NASH) and metabolic syndrome, and 137 matched controls found that serum total cholesterol was significantly higher in PBC and NASH patients than in controls $(221.6 \mathrm{mg} / \mathrm{dL}$ vs. 221.7 $\mathrm{mg} / \mathrm{dL}$ vs. $209.8 \mathrm{mg} / \mathrm{dL}$ respectively, $p<0.05$ ) with serum adiponectin, resistin and leptin concentrations significantly higher in PBC patients than either NASH patients or controls $(p<0.05) .{ }^{31}$ Further analysis showed that adiponectin correlated with histological progression of $\operatorname{PBC}(p=0.001)$ and negatively with body mass index $(p=0.01)$. The authors concluded that the increase in adiponectin found in patients with PBC may contribute to the lower-than-expected levels of atherosclerosis seen in this population.

Patients with hypercholesterolemia and PBC have a substantial portion of circulating lipoprotein $X$, which has been shown to reduce atherogenicity of LDL cholesterol by preventing LDL oxidation. ${ }^{32}$ Su et al. ${ }^{33}$ evaluated LDL oxidation times in 13 patients with $\mathrm{PBC}$ with hypercholesterolemia compared to 71 controls with hypercholesterolemia and found a significantly increased delay in the PBC group (192.4 m vs $144.2 \mathrm{~m}$, $p=0.03) .{ }^{33}$ There was no significant difference in the intimamedia thickness (IMT) of the common carotid artery and plaque scores for the extracranial carotid artery between the two groups. Additionally, serum antioxidant activity is reportedly elevated in patients with PBC, having a strong positive correlation with bilirubin levels. ${ }^{34}$ 
Suraweera D. et al: Cardiovascular risk in PBC

Table 2. Studies evaluating lipid profiles in primary biliary cholangitis

\begin{tabular}{|c|c|c|c|}
\hline Author & Country & Comparison groups & Findings \\
\hline $\begin{array}{l}\text { Baruch et al. }{ }^{20} \\
1984\end{array}$ & Israel & $\begin{array}{l}7 \text { female PBC patient compared } \\
\text { with } 6 \text { age-matched controls }\end{array}$ & $\begin{array}{l}\text { Increased HDL and decreased platelet } \\
\text { aggregation in PBC patients }\end{array}$ \\
\hline $\begin{array}{l}\text { Crippin et al. }{ }^{17} \\
1992\end{array}$ & USA & $\begin{array}{l}312 \text { patients with } \mathrm{PBC} \text { compared } \\
\text { to age- and sex-matched controls }\end{array}$ & Increased $\mathrm{HDL}$ in $\mathrm{PBC}$ patients \\
\hline $\begin{array}{l}\text { Gregory et al. }{ }^{27} \\
1994\end{array}$ & UK & $\begin{array}{l}42 \text { patients with } \mathrm{PBC} \text { compared to } \\
39 \text { age- and sex-matched subjects } \\
\text { with non-PBC liver disease and } \\
432 \text { community control subjects }\end{array}$ & $\begin{array}{l}\text { Decreased lipoprotein(a) concentrations in } \\
\text { the PBC group compared with the healthy } \\
\text { controls }(28.5 \mathrm{mg} / \mathrm{L} \text { vs. } 75.0 \mathrm{mg} / \mathrm{L} \text {, } \\
p<0.005)\end{array}$ \\
\hline $\begin{array}{l}\text { Romics et al. }{ }^{26} \\
1996\end{array}$ & Hungary & $\begin{array}{l}39 \text { female PBC patients compared } \\
\text { to } 39 \text { female controls }\end{array}$ & $\begin{array}{l}\text { Despite the elevation of overall lipoproteins } \\
\text { in PBC patients, there was no difference in } \\
\text { lipoprotein }(\mathrm{a}) \text { levels between the two } \\
\text { groups }(10 \mathrm{mg} / \mathrm{dL} \text { vs. } 11.5 \mathrm{mg} / \mathrm{dL}, p=0.64)\end{array}$ \\
\hline $\begin{array}{l}\text { O'Kane et al. } \\
1997\end{array}$ & UK & $\begin{array}{l}31 \text { patients with } \mathrm{PBC} \text { compared to } \\
27 \text { control subjects }\end{array}$ & $\begin{array}{l}\text { PBC is associated with an altered } \\
\text { distribution of apolipoprotein A } 1 \text { favoring an } \\
\text { increased concentration of the protective } \\
\text { LpA-I particle }\end{array}$ \\
\hline $\begin{array}{l}\text { Chang et al. }{ }^{32} \\
2004\end{array}$ & Taiwan & $\begin{array}{l}6 \text { PBC patients compared to } \\
\text { healthy controls }\end{array}$ & $\begin{array}{l}\text { Patients with hypercholesterolemia and PBC } \\
\text { have a substantial portion of circulating } \\
\text { lipoprotein X }\end{array}$ \\
\hline $\begin{array}{l}\text { Su et al. }{ }^{33} \\
2007\end{array}$ & Taiwan & $\begin{array}{l}13 \text { PBC patients compared to age- } \\
\text { matched } 71 \text { patients with } \\
\text { hypercholesterolemia }\end{array}$ & $\begin{array}{l}\text { Prolonged LDL oxidation lag time in patients } \\
\text { with PBC }\end{array}$ \\
\hline $\begin{array}{l}\text { Floreani et al. }{ }^{31} \\
2008\end{array}$ & Italy & $\begin{array}{l}137 \text { PBC patients compared with } \\
30 \text { patients with NASH/metabolic } \\
\text { syndrome and } 137 \text { matched } \\
\text { controls found that }\end{array}$ & $\begin{array}{l}\text { Significantly higher adiponectin, resistin } \\
\text { and leptin concentrations in PBC patients } \\
\text { than both NASH patients and controls } \\
(p<0.05)\end{array}$ \\
\hline
\end{tabular}

Studies have shown that the lipid profile in patients with PBC changed with progression of the disease. Jahn et al. ${ }^{35}$ noted that early and intermediate histologic stages of PBC displayed mild elevations of very low density lipoproteins (VLDL) and LDL, with marked increases in HDL. However, in patients with advanced disease, marked elevations in LDL with the presence of lipoprotein $X$ and a significant decrease in HDL were seen. These changes are likely multifactorial. Cholesterol absorption and synthesis is markedly reduced with severity of PBC along with a reduction in biliary cholesterol and bile acid secretion. ${ }^{36}$

Several studies have evaluated endothelial function in patients with $\mathrm{PBC}$ and concluded that hypercholesterolemia in $\mathrm{PBC}$ is not associated with subclinical atherosclerosis. Cash et al. ${ }^{12}$ compared 51 PBC patients to 34 control subjects and found that PBC patients appeared to have increased endothelial dysfunction and inflammation, while concurrently having a deficiency in antioxidants. C-reactive protein, sICAM and sVCAM were significantly elevated in PBC patients (469.14 vs. $207.13, p<0.001 ; 768.12$ vs. $308.03, p<0.001$; 708.40 vs. $461.31, p<0.001)$, whereas antioxidants such as ascorbate, vitamin $\mathrm{E}$ and vitamin A were significantly lower in PBC patents ( 39.91 vs. $72.68, p<0.001 ; 2.63$ vs. $3.14, p=$ $0.02 ; 1.08$ vs. $1.81, p<0.001)$. However, the study also found that PBC patients had a lower pulse wave velocity $(8.22 \mathrm{~m} / \mathrm{s}$ vs. $8.78 \mathrm{~m} / \mathrm{s}, p=0.022$ ), indicating a possible lower cardiovascular risk. Alloca et al. ${ }^{11}$ looked at IMT and stenosis of the carotid arteries to evaluate for atherosclerosis in 103 PBC patients compared to 37 control patients with hypercholesterolemia and 141 controls with normal cholesterol levels. The authors found that controls with hypercholesterolemia had a higher IMT and prevalence of carotid stenosis when compared to PBC patients with hypercholesterolemia $(0.292 \mathrm{~mm}$ vs. $0.616 \mathrm{~mm}, p<0.00 ; 43 \%$ vs. $19 \%, p=0.129)$. The authors concluded that hypercholesterolemia is not associated with subclinical atherosclerosis in patients with PBC.

\section{Cardiovascular risk and comorbidities}

Patients with PBC who have additional cardiovascular risk factors other than hypercholesterolemia do have a higher risk for cardiovascular disease (Table 3 ). A prospective Italian cohort study of 400 patients with PBC for 6.2 years found that, although there was a similar incidence of cardiovascular events, concurrent hypertension was associated with an increased risk of cardiovascular events compared to the general population. ${ }^{37} \mathrm{~A}$ similar conclusion was reached in a study by Wang et al. ${ }^{38}$ evaluating 41 patients with PBC and coronary artery disease among 2,675 PBC cases over 7 years. In the logistic regression, hypertension was selected (with vs. without, $p<0.001$; odds ratio: $1.597 ; 95 \% \mathrm{CI}: 1.139-2.05$ ), and the authors concluded that PBC patients with concomitant hypertension should be monitored carefully for coronary artery disease.

Metabolic syndrome is an important risk factor for cardiovascular disease in the general population. Likewise, patients with PBC and metabolic syndrome may be at a higher risk of cardiovascular events. This is supported by a study from Floreani et al. ${ }^{7}$ comparing 171 PBC patients to 55 patients with $\mathrm{PBC}$ and concomitant metabolic syndrome, finding 
Suraweera D. et al: Cardiovascular risk in PBC

Table 3. Studies evaluating cardiovascular risk in patients with primary biliary cholangitis with additional comorbidities

\begin{tabular}{|c|c|c|c|c|c|}
\hline Author & Country & Methodology & Period & Comparison groups & Findings \\
\hline $\begin{array}{l}\text { Longo et al. }{ }^{37} \\
2002\end{array}$ & Italy & $\begin{array}{l}\text { Prospective } \\
\text { cohort study }\end{array}$ & Median 6.2 years & $\begin{array}{l}400 \text { patients with PBC } \\
\text { compared to rates of } \\
\text { disease in the general } \\
\text { population }\end{array}$ & $\begin{array}{l}\text { Subgroup analysis showed } \\
\text { PBC patients with } \\
\text { concurrent hypertension } \\
\text { had significantly increased } \\
\text { risk of cardiovascular events }\end{array}$ \\
\hline $\begin{array}{l}\text { Wang et al. }{ }^{38} \\
2004\end{array}$ & China & $\begin{array}{l}\text { Retrospective } \\
\text { cohort study }\end{array}$ & 7 years & $\begin{array}{l}41 \text { patients with PBC with } \\
\text { coronary heart disease } \\
\text { compared to patients } \\
\text { with PBC without } \\
\text { coronary heart disease }\end{array}$ & $\begin{array}{l}\text { Patients with coronary } \\
\text { artery disease had higher } \\
\text { mean cholesterol }(4.68 \\
\text { mmol/L vs. } 3.52 \mathrm{mmol} / \mathrm{L}, \\
p=0.036) \text { and higher } \\
\text { proportion had hypertension } \\
(63.4 \% \text { vs. } 19.5 \% \text {, } \\
p<0.001)\end{array}$ \\
\hline $\begin{array}{l}\text { Floreani et al. }{ }^{7} \\
2015\end{array}$ & Italy & $\begin{array}{l}\text { Retrospective } \\
\text { cohort study }\end{array}$ & $\begin{array}{l}\text { Database from } \\
1975-2011 \text { with } \\
\text { mean } 10.2 \text { years }\end{array}$ & $\begin{array}{l}55 \text { patients with PBC with } \\
\text { metabolic syndrome } \\
\text { compared to } 116 \text { PBC } \\
\text { patients without } \\
\text { metabolic syndrome }\end{array}$ & $\begin{array}{l}\text { Significantly more } \\
\text { cardiovascular events in } \\
\text { patients with metabolic } \\
\text { syndrome }(p<0.0001)\end{array}$ \\
\hline
\end{tabular}

a significantly higher incidence of cardiovascular events $(p<0.0001)$ in patients with metabolic syndrome. ${ }^{7}$ Interestingly, PBC patients may be at a lower risk for actually developing metabolic syndrome. Alempijevic et al. ${ }^{39}$ looked at 40 patients with $\mathrm{PBC}$ compared to 50 matched controls, and found significantly decreased visceral fat in the PBC patients compared to the controls $(10.92 \pm 3.63 \mathrm{~mm}$ vs. $16.84 \pm 5.51 \mathrm{~mm}$ ). Visceral fat has a strong correlation with developing metabolic syndrome. ${ }^{40}$ Another study by Alempijevic et al. ${ }^{41}$ found no statistically significant increase in metabolic syndrome in PBC patients when compared to matched controls, even though patients with PBC had significantly higher levels of cholesterol. The authors concluded that lower levels of visceral fat may play a role in the lower incidence of cardiovascular evens in patients with PBC.

\section{Lipid-lowering treatment}

Ursodeoxycholic acid (UDCA) is the first-line treatment for PBC. ${ }^{42}$ UDCA has also been shown to have lipid-lowering properties. Poupon et al. ${ }^{43}$ evaluated the effects of longterm UDCA on 17 patients with PBC compared to 16 patients with $\mathrm{PBC}$ receiving placebo for 2 years. The total serum cholesterol was significantly reduced in the UDCA-treated group compared to the placebo-treated group $(p<0.02)$. A randomized, placebo-controlled study evaluating the effects of UDCA on serum lipids in 177 PBC patients found a significant decrease in total cholesterol levels at 1 and 2 years of treatment. ${ }^{44}$ Of note, there was no significant effect on HDL or triglyceride levels. The authors found that the change in the serum cholesterol levels at 2 years was strongly correlated with the change in serum bilirubin $(r=0.70 ; p<0.001)$, which may indicate that the cholesterol-lowering effect of UDCA may be related to improvements in the underlying liver disease versus a direct effect on cholesterol metabolism.

Statin therapy has been the mainstay of treatment of hyperlipidemia in the general population and an important medication in the treatment and prevention of cardiovascular disease. Statin therapy has also been shown to be effective in cholesterol reduction in the PBC population (Table 4). One study by Del Puppo et al. ${ }^{45}$ involving 6 patients with PBC treated with simvastatin found a $34 \%$ decrease in cholesterol levels in 30 days. In a randomized, placebo-matched study involving 21 PBC patients treated with simvastatin $(20 \mathrm{mg}$ daily), patients in the treatment arm were noted to have decreased lipid hydroperoxides $(0.49 \mu \mathrm{mol} / \mathrm{L}$ vs. $0.59 \mu \mathrm{mol} / \mathrm{L}$, $p=0.10$ ) while having a slight increase in vitamin $C$ levels (80.54 $\mu \mathrm{mol} / \mathrm{L}$ vs. $77.40 \mu \mathrm{mol} / \mathrm{L}, p=0.95)$ after 12 months of treatment. ${ }^{46}$ As expected, LDL levels decreased significantly $(2.33 \mathrm{mmol} / \mathrm{L}$ vs. $3.53 \mathrm{mmol} / \mathrm{L}, p=0.01)$ and were significantly lower than in the placebo group $(4.91 \mathrm{mmol} / \mathrm{L}$ vs. 6.15 $\mathrm{mmol} / \mathrm{L}, p=0.01)$. However, there was no significant difference in pulse wave velocities of the two groups $(8.45 \mathrm{~m} / \mathrm{s}$ vs. $8.80 \mathrm{~m} / \mathrm{s}, p=0.66)$.

The use of atorvastatin has also been studied. In one retrospective analysis of 15 hypercholesterolemia patients with $\mathrm{PBC}$ compared to matched controls found that, while atorvastatin use led to significant decrease in total cholesterol and LDL $(p<0.002)$, there was no significant difference in aminotransferase, alkaline phosphatase, total bilirubin or Mayo risk score. ${ }^{47} \mathrm{~A}$ similar conclusion was reached in a study looking at the use of atorvastatin in patients with an incomplete biochemical response to UDCA. The authors concluded that, while atorvastatin did not improve cholestasis in patients with $\mathrm{PBC}$, it was effective in reducing serum cholesterol. ${ }^{48}$ A prospective, single-center study of 26 PBC patients treated with atorvastatin ( $10 \mathrm{mg}$ daily) for 48 weeks showed a reduction in cholesterol levels, endothelial inflammation and improved vascular function. ${ }^{49}$ Vascular status was measured via flow-mediated dilation and showed a significant improvement (from $7.16 \%$ to $8.36 \%, p<0.05$ ). Serum LDL cholesterol levels decreased significantly (from $171 \mathrm{mg} / \mathrm{dL}$ to 112 $\mathrm{mg} / \mathrm{dL}, p<0.001)$.

\section{Discussion}

Our systematic literature review yielded several key findings. The majority of studies evaluated did not show a statistically 
Suraweera D. et al: Cardiovascular risk in PBC

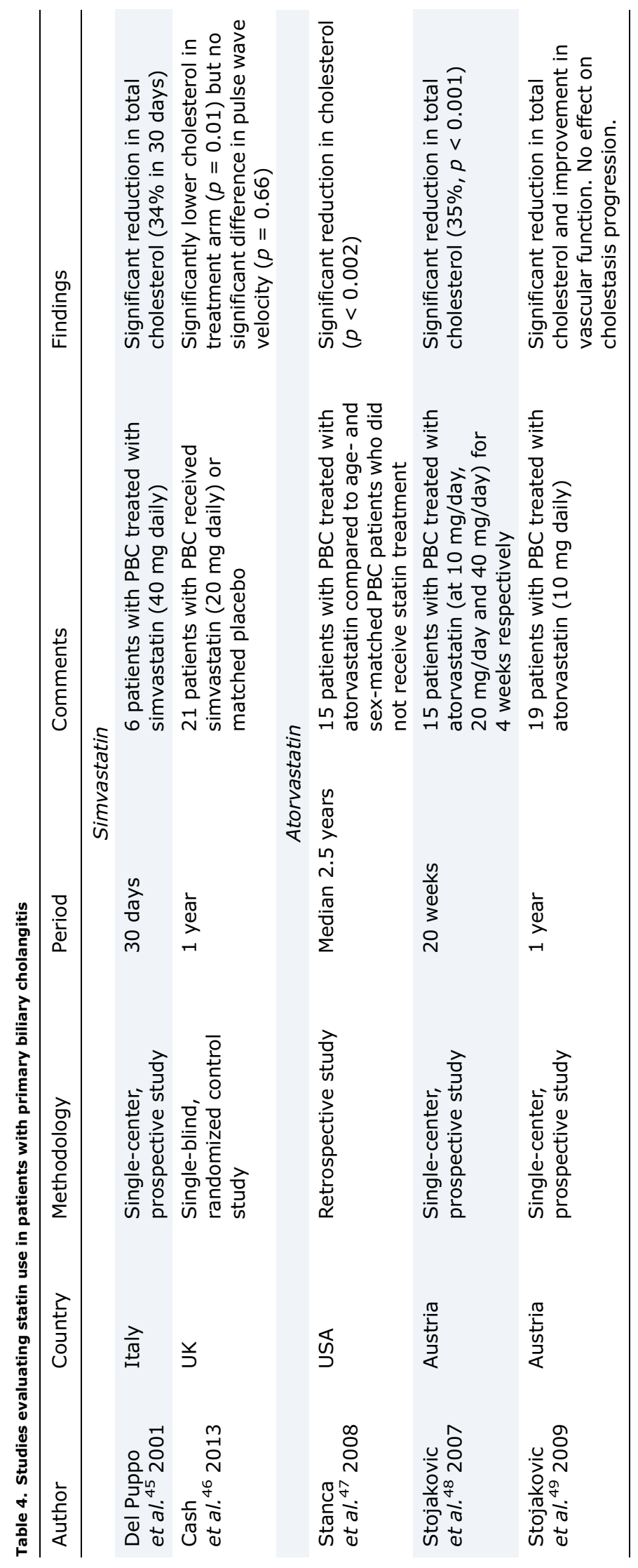


significant difference in cardiovascular disease for patients with PBC when compared to age- and sex-matched controls. However, a large Swedish study did find a significantly higher risk for coronary artery disease in patients with PBC. ${ }^{14}$ Furthermore, a systematic review of four observational studies found a statistically significant risk of coronary artery disease, even though individually the studies did not reach statistical significance. ${ }^{9}$ These discrepancies are difficult to reconcile with the currently available data. Larger studies will be needed to provide a better understanding of true cardiovascular risk.

There is a growing body of literature on the uniqueness of the lipid profile in patients with PBC with hypercholesterolemia. Higher HDL concentrations, decreased harmful lipoprotein(a) concentrations, increased protective LPA-I, adiponectin, resistin and leptin concentrations have been observed. ${ }^{17,20,24,26,27,31}$ While this lipid profile is certainly dynamic and evolves with the progression of $\mathrm{PBC}$, there is evidence to suggest that the specific lipid profile in PBC may have lower atherogenicity than in patients with hypercholesterolemia without PBC (Fig. 2). This may explain the lack of an obvious correlation between hypercholesterolemia and cardiovascular disease in PBC patients compared to the general population. Further research into lipid profiles in PBC patients may yield important findings in lipid metabolism and anthogenesis that will not only help PBC patients but possibly non-PBC patients with hypercholesterolemia.

UDCA is the mainstay in PBC treatment. It also has concomitant lipid-lowering properties that further enhance its benefit in patients with hypercholesterolemia. Several studies have showed that UDCA significantly decreases total cholesterol. ${ }^{43,44}$ However, the decrease in cholesterol levels were strongly correlated to serum bilirubin levels, suggesting its primary lipid-lowering effect occurs via improvement of underlying liver disease from PBC. A primary lipid-lowering agent, such as a statin, may be of benefit in patients who do not fully respond to UDCA.

Patients with PBC-associated hypercholesterolemia and additional risk factors for cardiovascular disease are indeed at a higher risk for developing cardiovascular disease. Statin treatment is effective in treating hypercholesterolemia in PBC patients, and we agree with previous recommendations of strongly considering treatment when additional cardiovascular risk factors are present. ${ }^{50}$ However, there is currently not

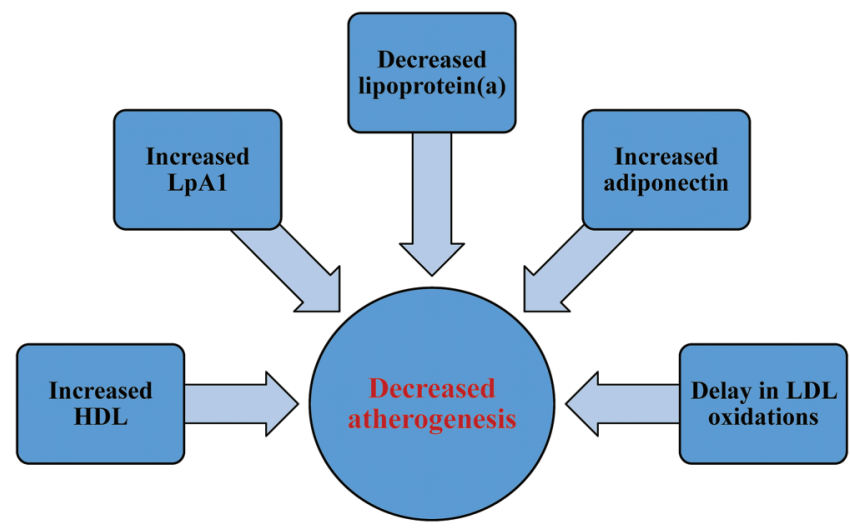

Fig. 2. Factors contributing to possible decreased anthogenesis in PBC patients with hypercholesterolemia compared to non-PBC patients with hypercholesterolemia. Abbreviation: PBC, primary biliary cholangitis. enough evidence to suggest an increased risk in cardiovascular disease in patients with PBC-related hypercholesterolemia without additional cardiovascular risk factors. For these patients, treatment should be based on prognosis and discussion with the patient.

There are several limitations with our systematic literature review. There are only a small number of large, longitudinal, population-based studies published, the likes of which would be needed to accurately evaluate cardiovascular risk in the PBC population. Thus, the conclusions made in this review are limited by the current data available, which are, at times, inconsistent. Furthermore, due to the relative rarity of PBC and the limited studies available, we were inclusive in our review. There were significant differences in methodologies and quality of the studies included and, consequently, it is difficult to provide recommendations based on conclusive evidence.

Over the last decade there have been significant new advancements in understanding cardiovascular risk in patients with PBC. While the majority of studies have not found an increase in cardiovascular disease in this population, further longitudinal data is needed to truly elucidate the risk.

\section{Conflict of interest}

The authors have no conflict of interests related to this publication.

\section{Author contributions}

Study concept and design (MJ, SS), acquisition of data (DS, $C F$ ), analysis and interpretation of data (DS, CF, MJ, SS), drafting of the manuscript (DS, CF), critical revision of the manuscript for important intellectual content (MJ, MJT, SS), administrative, technical, or material support, study supervision (SS).

\section{References}

[1] Ross R. Atherosclerosis-an inflammatory disease. N Engl J Med 1999;340: 115-126. doi: 10.1056/NEJM199901143400207.

[2] Kaplan MM, Gershwin ME. Primary biliary cirrhosis. N Engl J Med 2005;353: 1261-1273. doi: 10.1056/NEJMra043898.

[3] Boonstra K, Beuers U, Ponsioen CY. Epidemiology of primary sclerosing cholangitis and primary biliary cirrhosis: a systematic review. J Hepatol 2012;56: 1181-1188. doi: 10.1016/j.jhep.2011.10.025.

[4] Lindor KD, Gershwin ME, Poupon R, Kaplan M, Bergasa NV, Heathcote EJ. Primary biliary cirrhosis. Hepatology 2009;50:291-308. doi: 10.1002/hep. 22906.

[5] Goldblatt J, Taylor PJ, Lipman T, Prince MI, Baragiotta A, Bassendine MF, et al. The true impact of fatigue in primary biliary cirrhosis: a population study. Gastroenterology 2002;122:1235-1241. doi: 10.1053/gast.2002.32993.

[6] Jones DE, Hollingsworth K, Fattakhova G, MacGowan G, Taylor R, Blamire A, et al. Impaired cardiovascular function in primary biliary cirrhosis. Am J Physiol Gastrointest Liver Physiol 2010;298:G764-G773. doi: 10.1152/ajpgi.00501. 2009.

[7] Floreani A, Cazzagon N, Franceschet I, Canesso F, Salmaso L, Baldo V. Metabolic syndrome associated with primary biliary cirrhosis. J Clin Gastroenterol 2015:49:57-60. doi: 10.1097/MCG.0000000000000029.

[8] Zalewski P, Jones D, Lewis I, Frith J, Newton JL. Reduced thoracic fluid content in early-stage primary biliary cirrhosis that associates with impaired cardiac inotropy. Am J Physiol Gastrointest Liver Physiol 2013;305:G393G397. doi: 10.1152/ajpgi.00097.2013.

[9] Ungprasert P, Wijarnpreecha K, Ahuja W, Spanuchart I, Thongprayoon C. Coronary artery disease in primary biliary cirrhosis: A systematic review and meta-analysis of observational studies. Hepatol Res 2015;45:10551061. doi: 10.1111/hepr.12452.

[10] Doycheva I, Chen C, Pan JJ, Levy C. Asymptomatic primary biliary cirrhosis is not associated with increased frequency of cardiovascular disease. World J Hepatol 2011;3:93-98. doi: 10.4254/wjh.v3.i4.93. 
[11] Allocca M, Crosignani A, Gritti A, Ghilardi G, Gobatti D, Caruso D, et al. Hypercholesterolaemia is not associated with early atherosclerotic lesions in primary biliary cirrhosis. Gut 2006;55:1795-1800. doi: 10.1136/gut. 2005.079814.

[12] Cash WJ, McCance DR, Young IS, McEneny J, Cadden IS, McDougall NI, et al. Primary biliary cirrhosis is associated with oxidative stress and endothelial dysfunction but not increased cardiovascular risk. Hepatol Res 2010;40: 1098-1106. doi: 10.1111/j.1872-034X.2010.00717.x.

[13] Ungprasert P, Wijarnpreecha K, Thongprayoon C. Risk of cerebrovascular accident in patients with primary biliary cirrhosis: a systematic review and meta-analysis. Eur J Gastroenterol Hepatol 2016;28:90-94. doi: 10.1097/ MEG.0000000000000493.

[14] Zöller B, Li X, Sundquist J, Sundquist K. Risk of subsequent coronary heart disease in patients hospitalized for immune-mediated diseases: a nationwide follow-up study from Sweden. PLoS One 2012;7:e33442. doi: 10. 1371/journal.pone.0033442.

[15] Solaymani-Dodaran M1, Aithal GP, Card T, West J. Risk of cardiovascular and cerebrovascular events in primary biliary cirrhosis: a population-based cohort study. Am J Gastroenterol 2008;103:2784-2788. doi: 10.1111/j. 1572-0241.2008.02092.x.

[16] Van Dam GM, Gips CH. Primary biliary cirrhosis in The Netherlands. An analysis of associated diseases, cardiovascular risk, and malignancies on the basis of mortality figures. Scand J Gastroenterol 1997;32:77-83. doi: 10. 3109/00365529709025067.

[17] Crippin JS, Lindor KD, Jorgensen R, Kottke BA, Harrison JM, Murtaugh PA, et al. Hypercholesterolemia and atherosclerosis in primary biliary cirrhosis: what is the risk? Hepatology 1992;15:858-862. doi: 10.1002/hep.1840150518.

[18] Sorokin A, Brown JL, Thompson PD. Primary biliary cirrhosis, hyperlipidemia and atherosclerotic risk: a systematic review. Atherosclerosis 2007;194: 293-299. doi: 10.1016/j.atherosclerosis.2006.11.036.

[19] Enjoji M, Yada R, Fujino T, Yoshimoto T, Yada M, Harada N, et al. The state of cholesterol metabolism in the liver of patients with primary biliary cirrhosis: the role of MDR3 expression. Hepatol Int 2009;3:490-496. doi: 10. 1007/s12072-009-9137-y.

[20] Baruch Y, Brook JG, Eidelman S, Aviram M. Increased concentration of high density lipoprotein in plasma and decreased platelet aggregation in primary biliary cirrhosis. Atherosclerosis 1984;53:151-162. doi: 10.1016/00219150(84)90191-6.

[21] Gordon T, Castelli WP, Hjortland MC, Kannel WB, Dawber TR. High density lipoprotein as a protective factor against coronary heart disease. The Framingham Study. Am J Med 1977;62:707-714. doi: 10.1016/0002-9343(77) 90874-9.

[22] Fruchart JC, Ailhaud G. Apolipoprotein A-containing lipoprotein particles: physiological role, quantification, and clinical significance. Clin Chem 1992; 38:793-797.

[23] Puchois $P$, Kandoussi $A$, Fievet $P$, Fourrier JL, Bertrand $M$, Koren $E$, et al. Apolipoprotein A-I containing lipoproteins in coronary artery disease. Atherosclerosis 1987;68:35-40. doi: 10.1016/0021-9150(87)90091-8.

[24] O'Kane MJ, Lynch PL, Callender ME, Trimble ER. Abnormalities of serum apo A1 containing lipoprotein particles in patients with primary biliary cirrhosis. Atherosclerosis 1997;131:203-210. doi: 10.1016/S0021-9150(97)06108-X.

[25] Danesh J1, Collins R, Peto R. Lipoprotein(a) and coronary heart disease. Meta-analysis of prospective studies. Circulation 2000;102:1082-1085. doi: 10.1161/01.CIR.102.10.1082.

[26] Romics L, Nemesánszky E, Szalay F, Császár A, Tresch J, Karádi I. Lipoprotein(a) concentration and phenotypes in primary biliary cirrhosis. Clin Chim Acta 1996;255:165-171. doi: 10.1016/0009-8981(96)06404-2.

[27] Gregory WL, Game FL, Farrer M, Idle JR, Laker MF, James OF. Reduced serum lipoprotein (a) levels in patients with primary biliary cirrhosis. Atherosclerosis 1994;105:43-50. doi: 10.1016/0021-9150(94)90006-X.

[28] Ben-Ari Z, Tur-Kaspa R, Schafer Z, Baruch Y, Sulkes J, Atzmon O, et al. Basal and post-methionine serum homocysteine and lipoprotein abnormalities in patients with chronic liver disease. J Investig Med 2001;49:325-329. doi: 10.2310/6650.2001.33897.

[29] Maahs DM, Ogden LG, Kinney GL, Wadwa P, Snell-Bergeon JK, Dabelea D, et al. Low plasma adiponectin levels predict progression of coronary artery calcification. Circulation 2005;111:747-753. doi: 10.1161/01.CIR.0000155251. 03724.A5.

[30] Díez JJ, Iglesias P. The role of the novel adipocyte-derived hormone adiponectin in human disease. Eur J Endocrinol 2003;148:293-300. doi: 10. 1530/eje.0.1480293.
[31] Floreani A, Variola A, Niro G, Premoli A, Baldo V, Gambino R, et al. Plasma adiponectin levels in primary biliary cirrhosis: a novel perspective for link between hypercholesterolemia and protection against atherosclerosis. Am J Gastroenterol 2008;103:1959-1965. doi: 10.1111/j.1572-0241.2008. 01888.x.

[32] Chang PY, Lu SC, Su TC, Chou SF, Huang WH, Morrisett JD, et al. Lipoprotein-X reduces $L D L$ atherogenicity in primary biliary cirrhosis by preventing LDL oxidation. J Lipid Res 2004;45:2116-2122. doi: 10.1194/jlr.M400229-JLR200.

[33] Su TC, Hwang JJ, Kao JH. Hypercholesterolemia in primary biliary cirrhosis. $\mathrm{N}$ Engl J Med 2007;357:1561-1562. doi: 10.1056/NEJMc071467.

[34] Dudnik LB, Azyzova OA, Solovyova NP, Savchenkova AP, Pokrovskaya MA. Primary biliary cirrhosis and coronary atherosclerosis: protective antioxidant effect of bilirubin. Bull Exp Biol Med 2008;145:18-22. doi: 10.1007/s10517008-0019-4

[35] Jahn CE, Schaefer EJ, Taam LA, Hoofnagle JH, Lindgren FT, Albers J], et al. Lipoprotein abnormalities in primary biliary cirrhosis. Association with hepatic lipase inhibition as well as altered cholesterol esterification. Gastroenterology 1985;89:1266-1278. doi: 10.1016/0016-5085(85)90642-0.

[36] Gylling H, Färkkilä M, Vuoristo M, Miettinen TA. Metabolism of cholesterol and low- and high-density lipoproteins in primary biliary cirrhosis: cholesterol absorption and synthesis related to lipoprotein levels and their kinetics. Hepatology 1995;21:89-95. doi: 10.1002/hep.1840210116.

[37] Longo M, Crosignani A, Battezzati PM, Squarcia Giussani C, Invernizzi P, Zuin $\mathrm{M}$, et al. Hyperlipidaemic state and cardiovascular risk in primary biliary cirrhosis. Gut 2002;51:265-269. doi: 10.1136/gut.51.2.265.

[38] Wang C, Zhao P, Liu W. Risk of incident coronary artery disease in patients with primary biliary cirrhosis. Int J Clin Exp Med 2014;7:2921-2924.

[39] Alempijević T, Jesić R, Svorcan P, Milutinović AS, Kovacević N, Radaljac T, et al. Ultrasound measurement of visceral fat in patients with primary biliary cirrhosis. Vojnosanit Pregl 2011;68:739-743. doi: 10.2298/VSP1109739A.

[40] Meriño-Ibarra E, Artieda M, Cenarro A, Goicoechea J, Calvo L, Guallar A, et al. Ultrasonography for the evaluation of visceral fat and the metabolic syndrome. Metabolism 2005;54:1230-1235. doi: 10.1016/j.metabol.2005.04.009.

[41] Alempijevic T, Sokic-Milutinovic A, Pavlovic Markovic A, Jesic-Vukicevic R, Milicic B, Macut D, et al. Assessment of metabolic syndrome in patients with primary biliary cirrhosis. Wien Klin Wochenschr 2012;124:251-255. doi: 10.1007/s00508-012-0162-9.

[42] Heathcote EJ. Management of primary biliary cirrhosis. The American Association for the Study of Liver Diseases practice guidelines. Hepatology 2000 31:1005-1013. doi: 10.1053/he.2000.5984.

[43] Poupon RE, Ouguerram K, Chrétien Y, Verneau C, Eschwège E, Magot $T$, et al. Cholesterol-lowering effect of ursodeoxycholic acid in patients with primary biliary cirrhosis. Hepatology 1993;17:577-582. doi: 10.1002/ hep. 1840170408.

[44] Balan V, Dickson ER, Jorgensen RA, Lindor KD. Effect of ursodeoxycholic acid on serum lipids of patients with primary biliary cirrhosis. Mayo Clin Proc 1994;69:923-929. doi: 10.1016/S0025-6196(12)61815-1.

[45] Del Puppo M, Galli Kienle M, Crosignani A, Petroni ML, Amati B, Zuin M, et al. Cholesterol metabolism in primary biliary cirrhosis during simvastatin and UDCA administration. J Lipid Res 2001;42:437-441.

[46] Cash WJ, O'Neill S, O'Donnell ME, McCance DR, Young IS, McEneny ], et al. Randomized controlled trial assessing the effect of simvastatin in primary biliary cirrhosis. Liver Int 2013;33:1166-1174. doi: 10.1111/liv.12191.

[47] Stanca CM, Bach N, Allina J, Bodian C, Bodenheimer H Jr, Odin JA. Atorvastatin does not improve liver biochemistries or Mayo Risk Score in primary biliary cirrhosis. Dig Dis Sci 2008;53:1988-1993. doi: 10.1007/s10620007-0003-2.

[48] Stojakovic T, Putz-Bankuti C, Fauler G, Scharnagl H, Wagner M, Stadlbauer V, et al. Atorvastatin in patients with primary biliary cirrhosis and incomplete biochemical response to ursodeoxycholic acid. Hepatology 2007;46:776784. doi: 10.1002/hep.21741.

[49] Stojakovic T, Claudel T, Putz-Bankuti C, Fauler G, Scharnagl H, Wagner M, et al. Low-dose atorvastatin improves dyslipidemia and vascular function in patients with primary biliary cirrhosis after one year of treatment. Atherosclerosis 2010;209:178-183. doi: 10.1016/j.atherosclerosis.2009.08.052.

[50] Balmer ML, Dufour JF. Treatment of hypercholesterolemia in patients with primary biliary cirrhosis might be more beneficial than indicated. Swiss Med Wkly 2008;138:415-419. doi: 10.2008/29/smw-12311. 